\title{
Self-Assessment of Educational Program for Quality Assurance: A Case Study on BS(Agriculture) Program of BSMRAU
}

\author{
Md. Safiul Islam Afrad ${ }^{1}$, Muhammad Ziaul Hoque ${ }^{2}$
}

\begin{tabular}{l} 
ARTICLE INFO \\
\hline Article History: \\
Received 27.12 .2019 \\
Received in revised form \\
16.05 .2020 \\
Accepted \\
Available online 01.07 .2020
\end{tabular}

\section{INTRODUCTION}

In the era of globalization, when intellectual capital is more and more valued both by individuals and nations then higher education has become significantly important (Busco, Dooner, \& D'Alencon, 2018). The standard of intellectual capital depends on the quality of teaching-learning, research facilities, laboratory facilities, library facilities, modernization of course curriculum, etc. Higher education can produce critical thinkers and innovators, as well as healthy, informed, and enthusiastic citizens (Chaudhary, Gillani, \& Iqbal, 2009). Quality higher education changes society and remains the center of change and development (Barnamala, 2015). Higher education endorses social mobility and a high standard of living (Chaudhary et al., 2009). Higher education has an enormous potential to promote prosperity in developing nations (Monem \& Baniamin, 2010). The deficiency of regulatory mechanisms in higher education has worn social trust (Geoffroy Pitta, 2014), especially for countries where university-level education is considered to be a driving force for social mobility and economic development (OECD, 2019; Torre \& Zapata, 2012). Hence, quality improvement following the analysis of past inadequacies is increasingly necessary for the higher education sector.

Ensuring education for all and assurance of quality education are the prime objectives of the Government of the People's Republic of Bangladesh (Rahman, 2010). Despite the remarkable achievements in quantitative indicators i.e. increasing number of universities and enrolled students, tertiary education in Bangladesh, currently, has been facing many deeply rooted and intertwined challenges. Quality higher education is a much-debated issue in Bangladesh nowadays (Sarkar, Rana, \& Zitu, 2013). Higher education will not succeed in achieving its goal to bring out enlightened, highly skilled, trained, motivated, and morally committed individuals if it fails to ensure quality comparable to the developed world. Consequently, the country will fail to achieve its development objectives. Hence, strengthening of higher education is required for enhancing the overall development of Bangladesh. It is generally agreed by academicians, education thinkers, education researchers, education policy planners, and other stakeholders that the quality of higher education in Bangladesh has been deteriorating steadily, in some areas quite alarmingly, over the last two decades (Aminuzzaman, 2011). However, it has not been evaluated and addressed properly the reasons for declining the quality of higher education in Bangladesh.

Self-assessment is considered as an organizational judgment (Rodr'iguez, 2005) driven by the representative of the same organization with wide involvement of all its stakeholders to generate better commitment, communication channels, and reassessing policies, methods, records, and culture (Villalta, 1998). The main proposition behind the objective of this type of research is that the evaluation itself offers organizational diagnosis, and assist in the further improvement of that organization (Schein, 2005).

1 e-mail: afrad@bsmrau.edu.bd, Bangabandhu Sheikh Mujibur Rahman Agricultural University, orcid.org/0000-0001-8193-5091

2 zia.bsmrau@gmail.com, Bangabandhu Sheikh Mujibur Rahman Agricultural University, orcid.org/0000-0001-6212-6969 
BSMRAU (Bangabandhu Sheikh Mujibur Rahman Agricultural University) is one of the leading academic and research-based agricultural university in Bangladesh. Meanwhile, the university has got national and international recognition for generating graduates who are contributing in the different national and international organization, and developing many agricultural crop varieties (Nasim et al., 2019) to ensure food security in the face of adverse climate change impact (Hoque, Cui, Xu, \& Islam, 2019), increasing population, and decreasing cultivable lands (Chowdhury, Haque, Hoque, \& Rokonuzzam, 2012; Hoque, Cui, Islam, Xu, \& Tang, 2020). Although BSMRAU has started its BS(Agriculture) program popularly known as BS(Ag) program in 2005 following North American course credit systems, it has not been evaluated yet the strength and weaknesses of the program to compare the global standards and get international accreditation. Considering the above-mentioned facts into account, a self-assessment was conducted to evaluate the quality of BS(Ag) program of BSMRAU in different aspects such as its curriculum, teachers and staffs, teaching-learning assessment system, institutional structure and facilities, knowledge and skill development, recruitment system, and student support and counseling. The findings of this study is intended to identify the strong and weak points of $\mathrm{BS}(\mathrm{Ag})$ program and help to plan future policies to improve its overall quality for getting national and international accreditation.

\section{Methodology}

Wide range of approaches and strategies were adopted to conduct the study (Figure 1). These included the formation of a self-assessment (SA) sub-committee and arrangement of a ten-day training program on different aspects of self-assessment including teaching methodology training workshops for the faculties of different tiers. The individual interview was conducted during 2012-2014 with purposively selected respondents covering varied stakeholders viz. faculty members (60), officers (15), students (160), alumni (30), administrators (10), laboratory assistants (18) and employers (15). The interview schedule used in this study was based on the national guideline for the program level self-assessment study of different universities. Five focus group discussions (FGD) were arranged with students, teachers, alumni, administrators, and staff. Three workshops were arranged with the aforesaid stakeholders considering the importance, benefits, assessment processes, and other related issues involved therein. One of the most important activities performed was face to face data collection from different stakeholders with interview schedules considering the objectives in view. A 4-point rating scale ranged from "strongly agree", "agree", disagree" and "strongly disagree" was employed to collect the opinion of the respondents and scores of ' 4 ', ' 3 ', ' 2 ' and ' 1 ' were assigned against each of these responses, respectively. A simple average score of each statement under different components were computed based on the opinion of the stakeholders and ranked for identified the strong and weak points. Moreover, an average score of $\geq 3.0$ was considered as highly satisfactory, while a score of $2.0-<3.0$ was moderately satisfactory and a score of less than 2.0 was considered as dissatisfactory. 


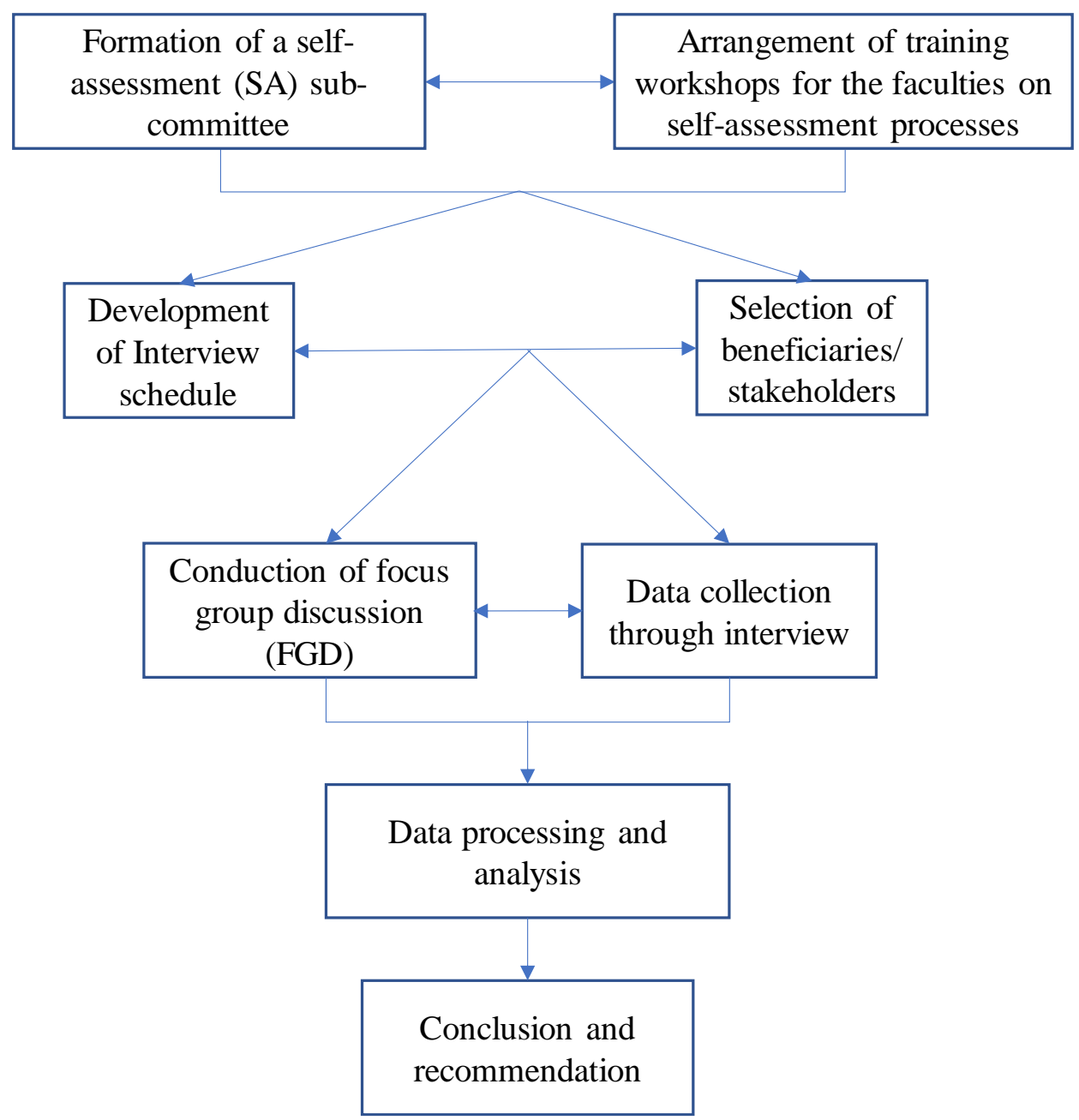

Figure 1. Flow diagram of the study

\section{Results and Discussion}

\subsection{Teaching-learning assessment}

Regarding teaching-learning strength and opportunity, respondents opined that teaching style had varied greatly from teacher to teacher (3.57) whereas satisfactory responses were found in completion of course content (3.22), preparation of the teacher for classes (3.12) and availability of the teacher during office hour (3.20). On the other hand, the provision of additional material apart from the book (2.55), the individual potentiality of students (2.53), and equal preferences for every student matter (2.47) was not found moderately satisfactory (Table 1a). Teachers vary from each other as per their length of teaching experience, degrees obtained, and training received on teaching methodology. These might be the reasons for variations in the delivery of different teachers. As the BS(Ag) program has been running under close supervision, each teacher gets enough preparation before conducting any class and most of the teachers remaining on the campus are available in their chambers even extra office hours. Therefore, these reasons might be responsible to get positive responses from the respondents. 
Table 1a. Opinions of the respondents on teaching-learning

\begin{tabular}{|c|c|c|c|}
\hline 1 & Statement & $\begin{array}{l}\text { Averag } \\
\text { e score }\end{array}$ & SD \\
\hline 1. & Teaching style greatly varies from teacher to teacher & 3.57 & 0.56 \\
\hline 2. & Teachers always complete the whole course content & 3.22 & 0.94 \\
\hline 3. & Teachers were available during the specified office hours & 3.20 & 0.70 \\
\hline 4. & Teachers are always found prepared for the classes & 3.12 & 0.83 \\
\hline 5. & Teachers maintained a conducive learning environment & 3.08 & 0.84 \\
\hline 6. & Teachers inspire students to become lifelong learner (LLL) & 3.06 & 0.91 \\
\hline 7. & Teaching and other academic activities facilitate the learning process & 3.05 & 0.66 \\
\hline 8. & The assignment and exams covered course content fully & 3.04 & 0.66 \\
\hline 9. & $\begin{array}{l}\text { Teaching and learning (T\&L) at the program level addresses the aims and } \\
\text { objectives of each subject }\end{array}$ & 3.03 & 0.95 \\
\hline 10. & $\begin{array}{l}\text { Teaching and learning enables students in reflecting on how, what, and why } \\
\text { they are learning }\end{array}$ & 3.00 & 0.90 \\
\hline 11. & Variety of teaching and learning strategies are used & 2.97 & 0.97 \\
\hline 12. & T\&L incorporates a range of teaching aids and tools & 2.97 & 1.08 \\
\hline 13. & T\&L are based on what students know and can do & 2.92 & 1.05 \\
\hline 14. & Teachers demonstrate knowledge of the subject matter clearly & 2.92 & 1.01 \\
\hline 15. & $\begin{array}{l}\text { Dean office always monitors and document, different issues of teaching- } \\
\text { learning }\end{array}$ & 2.89 & 0.85 \\
\hline 16. & The teaching activity promotes students' interaction & 2.89 & 0.64 \\
\hline 17. & Teachers arrive and leave on time in the class & 2.82 & 1.03 \\
\hline 18. & T\&L improve the English language proficiency of students & 2.78 & 0.89 \\
\hline 19. & T\&L support students to become actively responsible for their learning & 2.72 & 0.93 \\
\hline 20. & Students' workload is reasonably balanced & 2.72 & 0.82 \\
\hline 21. & Teachers communicate the subject matter effectively & 2.71 & 0.97 \\
\hline 22. & T\&L addresses the diversity of students' language needs & 2.67 & 0.92 \\
\hline 23. & After class teachers are available for consultations & 2.62 & 0.98 \\
\hline 24. & Students are encouraged to demonstrate their learning in a variety of ways & 2.61 & 1.04 \\
\hline 25. & Teachers provide additional material apart from the book & 2.55 & 0.92 \\
\hline 26. & The individual potential was explored by this program & 2.53 & 1.05 \\
\hline 27. & Teachers take care of every student equally & 2.47 & 1.06 \\
\hline
\end{tabular}

Learning is assessed through different criteria to grade a student. Based on learning assessment, students are classified into different categories which act as a basis for entering into any job or distribution of other facilities in the professional life of the individual. The highly positive side of assessment criteria was timely publishing progress report (3.56), criteria of assessment communicated in advance (3.55). Favorable responses were found in the fairness of the teacher in the examination system (3.12), maintaining specific assessment criteria (3.08), use of varieties of assessment tools (3.06), and representative questions included for evaluation (3.06). The database of assessment reports (2.42) and student's feedback on answer script (2.43) were not maintained properly (Table $1 b)$. 
Table 1b. Opinions of the respondents on learning assessment

\begin{tabular}{|c|c|c|c|}
\hline S1 & Statement & $\begin{array}{c}\text { Average } \\
\text { score }\end{array}$ & SD \\
\hline 1. & Students' progress are reported before the next term & 3.56 & 0.63 \\
\hline 2. & Assessment criteria are communicated in advance & 3.55 & 0.62 \\
\hline 3. & The teachers are found fair enough in the examination system & 3.12 & 0.95 \\
\hline 4. & Students are assessed based on specific assessment criteria & 3.08 & 1.04 \\
\hline 5. & Variety of strategies and tools are used to assess student learning & 3.06 & 0.99 \\
\hline 6. & The content of the examination is representative of the course material & 3.06 & 1.00 \\
\hline 7. & Overall mean score assessment process of students is satisfactory & 3.04 & 0.84 \\
\hline 8. & $\begin{array}{l}\text { Students get opportunities to participate and reflect on the assessment } \\
\text { of their work }\end{array}$ & 2.94 & 0.88 \\
\hline 9. & There is a system for recording students' progress properly & 2.94 & 0.86 \\
\hline 10. & $\begin{array}{l}\text { The students get sufficient feedback on each of other assessment before } \\
\text { the next one }\end{array}$ & 2.86 & 0.98 \\
\hline 11. & $\begin{array}{l}\text { Assessment criteria for reports, assignments, and exams are } \\
\text { unequivocal }\end{array}$ & 2.78 & 0.71 \\
\hline 12. & Students receive sufficient feedback on the assignments completed & 2.55 & 0.82 \\
\hline 13. & Teachers return the answer scripts timely for students' feedback & 2.43 & 0.89 \\
\hline 14. & $\begin{array}{l}\text { The undergraduate program maintains a database for assessing } \\
\text { teaching and learning }\end{array}$ & 2.42 & 0.86 \\
\hline
\end{tabular}

\subsection{Teachers and staff}

Teachers and staffs are the vital components of the classroom and laboratory as well. Information on quality, number, and availability of teachers and staffs has been provided in Table 2. Most of the respondents were highly satisfied with the quality of teachers (3.43) as well as laboratory technicians (3.20). Moderate satisfaction was found about the number of teachers (2.98), availability of teachers after office hours for consultation (2.92) while more laboratory technicians was demanded (2.67). All the teachers in BSMRAU have higher education on their allied subject matter and they have received various training for teaching and learning both in-home and abroad. There is a good relationship between the teacher and laboratory technicians in the laboratory to conduct practical classes; besides, the laboratory technicians receive formal and informal training and direction to operating equipment in the laboratory. Hence, the respondents showed their satisfaction with teachers and staff qualification. In BS(Ag) program, the total number of teachers is 103, and 21 of them are abroad for pursuing higher degrees. Again these teachers are simultaneously involved in the postgraduate program. Therefore, the number of faculty is not sufficient enough at present to operate the program smoothly. This might be the cause of moderate satisfaction on these issues as furnished in Table 2. 
Table 2. Respondent students' opinion on teachers and staff

\begin{tabular}{clcc}
\hline Sl & \multicolumn{1}{c}{ Statement } & Average score & SD \\
\hline 1. & Teachers are well qualified & 3.43 & 0.75 \\
2. & Laboratory technicians are well trained & 3.20 & 0.74 \\
3. & Number of teachers to operate the program is satisfactory & 2.98 & 0.98 \\
4. & Faculties are available for consultation after office hours & 2.92 & 0.87 \\
5. & Number of laboratory technicians/field assistant is enough & 2.67 & 1.15 \\
\hline
\end{tabular}

\subsection{Structure}

Structure means something made up of several physical parts that are held or put together in a particular way or the interrelation or arrangement of parts in a complex entity that constitute the organization. The BS(Ag) program is generally facilitated by some infrastructure which includes classroom, library, laboratory, cafeteria, academic building, auditorium, car parking area, administrative building, etc. An attempt has been made to find out the structural facilities of the faculty. Responses obtained in Table 3 revealed the number of laboratories (2.67), availability of seminar room (2.65), the structure of the library (2.32), number of the classroom (2.25), the structure of the cafeteria (2.24) were moderately satisfactory (Table 3). However, administrative buildings (1.88), conference center (1.76), car parking space (1.71), auditorium (1.71), and the existence of a departmental store (1.53) were recognized as dissatisfactory.

Table 3. Opinion of the respondents on infrastructural facilities

\begin{tabular}{llcc}
\hline SI & \multicolumn{1}{c}{ Statements } & Average score & SD \\
\hline 1. & Space in the academic building is adequate & 2.88 & 1.14 \\
2. & Administrative building is well spacious & 2.88 & 0.97 \\
3. & Faculty of Agriculture has diversified infrastructures & 2.69 & 0.84 \\
4. & Number of laboratories are adequate & 2.67 & 0.83 \\
5. & Audio-Visual room/seminar room is spacious enough & 2.65 & 0.90 \\
6. & Library is well developed & 2.32 & 0.92 \\
7. & Number of classroom is sufficient & 2.25 & 0.93 \\
8. & Well-developed central cafeteria & 2.24 & 0.90 \\
9. & Conference center is well developed and equipped & 1.76 & 0.82 \\
10. & Size of the BSMRAU auditorium is sufficiently large & 1.71 & 0.71 \\
11. & Adequate car parking spaces are available & 1.71 & 0.75 \\
12. & Departmental store is adequate with essential services & 1.53 & 0.66 \\
\hline
\end{tabular}

Before starting the BS(Ag) program in 2005, a two-storied building was established with ample scope of classroom and some laboratories. Besides, some decorated postgraduate laboratories were used for BS(Ag) program. The seminar room and library were established earlier and used as a readymade structure for the program. These might be the causes of the respondents' satisfaction. On the other hand, there is no departmental store, a demarcated car parking place as yet. The auditorium is under construction along with a conference room facility. Therefore, the respondents could not but be dissatisfied with these structural facilities.

\subsection{Library facilities}

The library is a source of books, journals, reports, periodicals, etc. required for academic and research purpose which are part of higher education. Results presented in Table 4 indicate the opinion of the respondents on library facilities. 
Table 4. Opinion of the respondents on library facilities

\begin{tabular}{|c|c|c|c|}
\hline S1 & Statements & $\begin{array}{c}\text { Average } \\
\text { score }\end{array}$ & SD \\
\hline 1. & Latest journals and periodicals are available in the library & 2.29 & 0.89 \\
\hline 2. & Total number of Books/Journals are adequate in the library & 2.24 & 0.91 \\
\hline 3. & Online provision for books and journals is enough & 2.18 & 0.89 \\
\hline 4. & Books and other services in the library are adequate & 2.02 & 0.85 \\
\hline 5. & $\begin{array}{l}\text { Self-operated photocopy services in the central library are } \\
\text { satisfactory }\end{array}$ & 1.59 & 0.69 \\
\hline 6. & Group study facilities are enough for students & 1.53 & 0.62 \\
\hline
\end{tabular}

Information shown in Table 4 indicates that respondents of all categories expressed moderate satisfaction regarding library facilities which included availability of the latest journal (2.29), availability of books and journals (2.24), and online provision for books (2.18). But facilities for self-operated photocopy service (1.59) and group study (1.53) were found unsatisfactory. Every year different books related to the different subject matter are purchased and internet facility in the library enable students net browsing which facilitates online access to different journal and books. These were probably the reasons to moderate satisfaction in the case of books and journals and online provision. On the other hand, there is an inadequate facility for small group discussion and no provision of photocopy for the students as per their demand which might be the cause of their dissatisfaction with the issues.

\subsection{Transport facilities}

Transport is a vital tool both for the individuals of all sections living within and outside the University campus. Transport facilities are not improving with the increasing number of teachers, students, and staff as well. Results are given in Table 5 hint that the bus service of BSMRAU is moderately satisfactory for campus residing teachers, staff, and students (2.12) whereas inadequate (2.0) for off-campus teachers, staff, and students.

Table 5. Opinion of the respondents on transport facilities

\begin{tabular}{llcr}
\hline S1 & \multicolumn{1}{c}{ Statements } & Average score & SD \\
\hline 1. & $\begin{array}{l}\text { Bus service for campus residing teachers, staffs and students is } \\
\text { enough }\end{array}$ & 2.12 & 1.01 \\
2. & $\begin{array}{l}\text { Bus service for teachers, students, and staffs living outside the } \\
\text { campus is adequate }\end{array}$ & 2.00 & 0.85 \\
\hline
\end{tabular}

\subsection{Medical facilities}

The medical center provides facilities for primary health care and minor treatment with a supply of common medicines. For this reason, the respondents showed a moderate opinion on medicine quality. Other opinions in this regard are furnished in Table 6.

Table 6. Opinion of the respondents on medical facilities

\begin{tabular}{llcc}
\hline Sl & \multicolumn{1}{c}{ Statements } & $\begin{array}{c}\text { Average } \\
\text { score }\end{array}$ & SD \\
\hline 1. & Quality of medicine in the health center is good & 2.23 & 0.92 \\
2. & Physician is available in the health center for 24-hour service & 1.78 & 0.81 \\
3. & Medical center facility with an ambulance is adequate & 1.65 & 0.77 \\
4. & There is a sufficient number of qualified doctors in the health center & 1.46 & 0.59 \\
5. & Health care facility is good & 1.45 & 0.52 \\
\hline
\end{tabular}

All the stakeholders were moderately satisfied with the quality of medicine (2.41) provided in the health care center whereas 24-hours service (1.78), availability of ambulance (1.65), and a sufficient number of qualified doctors (1.46) were highly demanded (Table 6). In some cases, students don't get proper treatment due to their miss management and unavailability of the medical staff. There is no well-facilitated 
pathology lab for diagnoses of major diseases, except for a simple blood test facility. Besides, there is only one ambulance is available in the medical center. For major treatments or complicated problems, the students are referred to the District Hospital that's why it is highly demanded by the respondents for the improvement of quality of medical services and facilities.

\subsection{Class room /office room facilities}

A well-structured classroom with necessary facilities always facilitates the teaching-learning process. On the other hand, a good office room facilitates the working environment. The opinion of the stakeholders on classroom and office room facilities has been presented in Table 7 reveal that the respondents were highly satisfied with teaching aid facilities in the classroom (3.24) whereas other facilities in the classrooms like modern facilities (2.98), comfortable accommodation (2.71), and washroom (2.29) were found moderately satisfactory. The office room for the teachers and staff (2.50) were found moderately satisfactory. Therefore, $\mathrm{BS}(\mathrm{Ag})$ program is running with satisfied class/office room facilities which are very essential for teachinglearning in higher education.

Table 7. Opinion of the respondents on class/office room facilities

\begin{tabular}{|c|c|c|c|}
\hline Sl & Statements & Average score & SD \\
\hline 1. & There are appropriate teaching aids in the classrooms & 3.24 & 0.86 \\
\hline 2. & Classrooms are well equipped with modern facilities & 2.98 & 1.05 \\
\hline 3. & $\begin{array}{l}\text { Classrooms are sufficient with adequate space for comfortable } \\
\text { accommodation }\end{array}$ & 2.71 & 1.15 \\
\hline 4. & Office room facilities are satisfactory & 2.50 & 1.17 \\
\hline 5. & Washroom facilities are good enough in BSMRAU & 2.29 & 0.90 \\
\hline
\end{tabular}

\subsection{Laboratory facilities}

The laboratory is an important means for demonstration and 'hands on' practice and learning of different scientific processes and events by the students. A well-equipped laboratory plays a pivotal role in learning by doing by the students. It is available from collected information in Table 8 that moderate satisfaction was found in a laboratory environment (2.95), accommodation (2.76), first aid (2.53), competency of staffs (2.47), and laboratory instruments (2.35) while laboratory structure (1.88) was found dissatisfactory.

Table 8. Opinion of the respondents on laboratory facilities

\begin{tabular}{llcc}
\hline S1 & \multicolumn{1}{c}{ Statements } & $\begin{array}{c}\text { Average } \\
\text { score }\end{array}$ & SD \\
\hline 1. & The laboratory environment is conducive to learning & 2.95 & 0.81 \\
2. & Lab has enough space to accommodate students in practical group & 2.76 & 1.15 \\
3. & Overall mean score quality of the laboratory is satisfactory & 2.76 & 0.85 \\
4. & The laboratory requirements are fulfilled by the department timely & 2.71 & 0.81 \\
5. & Availability of first aid facility in the lab is enough & 2.53 & 0.81 \\
6. & There is an adequate number of competent lab staffs in each laboratory & 2.47 & 0.90 \\
7. & Undergraduate laboratories are equipped with sophisticated instruments & 2.35 & 1.02 \\
8. & Laboratory used by the Faculty of Agriculture is well structured & 1.88 & 0.85 \\
\hline
\end{tabular}

Lab chemicals and instruments are collected in a laboratory through different projects continuously and enough laboratory staff has been recruited through development and revenue programs. Therefore, satisfactory opinions were found by the respondents. In some laboratories due to inappropriate structure students cannot run their laboratory operations including proper seeing and listening. Therefore, the respondents showed their discontent with these issues.

\subsection{ICT facilities}

ICTs are technologies that facilitate communication and the processing and transmission of information through the internet. ICT includes technologies and methods for storing, managing, and processing as well as communicating information. Modern life cannot be thought without ICT and for higher education, it is beyond description. Teachers search and collect different teaching material, plan their lessons, and give instruction through ICT. On the other hand, students prepare their assignments and other work as per 
instruction of the teacher through ICT. Information furnished in Table 9 indicates the opinions of the respondents related to ICT facilities available for the BS(Ag) program.

Table 9. Opinion of the respondents on ICT facilities

\begin{tabular}{llcc}
\hline SI & \multicolumn{1}{c}{ Statements } & $\begin{array}{c}\text { Average } \\
\text { score }\end{array}$ & SD \\
\hline 1. & IT and computer facility is enough & 2.69 & 0.99 \\
2. & Academic buildings are well linked with internet facility for students & 2.12 & 1.00 \\
3. & Students have good access to internet facility in the library & 1.80 & 0.79 \\
4. & Number of computers in the computer laboratory are sufficient & 1.78 & 0.82 \\
5. & Internet facilities including Wi-Fi are available & 1.35 & 0.51 \\
6. & Internet facility for students is available in dormitories & 1.14 & 0.93 \\
\hline
\end{tabular}

Results presented in Table 9 show that most of the respondents were moderately satisfied with ICT and computer facilities (2.69) and internet facilities in the academic building (2.12). But students access to internet service in the library (1.80), the number of computers in the lab (1.78), Wi-Fi facilities (1.35), and dormitories (1.14) were not found satisfactory. In BSMRAU, each theory class is equipped with multimedia and computer facilities along with net connection which might be the cause of moderate contentment on the issue of ICT and computer facility in the academic building. In the laboratory, there is no computer, multimedia projector, and internet facility except computer lab. The internet browsing facility in the BSMRAU library is very limited while no internet connection is available in the dormitory. Hence, ICT facilities are not up to the mark for BS(Ag) students. It is learned that a project has been undertaken to provide Wi-Fi and broadband connections on the whole campus which is supposed to mitigate ICT related problems shortly.

\subsection{Sports facilities}

There is a wise saying that a sound mind lives in a sound body. Sports and games make an individual healthy physically and mentally. For any educational institution, there must have a sports section that keeps the students engaged in sports and games side by side with education. Findings displayed in Table 10 indicate that sports facilities of BSMRAU as the most vulnerable sectors because most of the respondents demonstrated dissatisfaction with the arrangement of the competitive games (1.41), the availability of physical instructors (1.65), and facilities of the stadium, swimming pool, and gymnasium (1.65). In BSMRAU, there is a sports section with only one Assistant Director (Physical) with only one day labor. There is one playground that is simultaneously used for football, cricket, volleyball, and athletics. Therefore, students cannot make multiple choices at a time. There is no gymnasium with exercise instruments and the case is similar for indoor games and swimming pool. Hence, the respondents showed them detest on sports facilities of BSMRAU.

Table 10. Opinion of the respondents on sports facilities

\begin{tabular}{|c|c|c|c|}
\hline Sl & Statements & $\begin{array}{c}\text { Average } \\
\text { score }\end{array}$ & SD \\
\hline 1. & Physical instructor is readily available to the students & 1.65 & 0.77 \\
\hline 2. & Stadium, swimming pool, and gymnasium facility is available in BSMRAU & 1.65 & 0.82 \\
\hline 3. & $\begin{array}{l}\text { There are enough arrangements for competitive games and sports for the } \\
\text { students of BSMRAU }\end{array}$ & 1.41 & 0.64 \\
\hline
\end{tabular}

\subsection{Residential facilities}

In a technical University like BSMRAU, the residential opportunity is a must for proper studying of the students. Information presented in Table 11 trace that residential facilities for the students (2.94) were moderately satisfactory whereas for faculty members (1.88) it was recognized as dissatisfactory. But other facilities like prayer and common room (2.56), student dining facilities (2.53), and cultural and recreational facilities in the dormitory (2.41) have been found reasonable whereas residential facilities (1.41) for guests were found inadequate. 
Table 11. Opinion of the respondents on residential facilities

\begin{tabular}{llcc}
\hline SI & \multicolumn{1}{c}{ Statements } & $\begin{array}{c}\text { Average } \\
\text { score }\end{array}$ & SD \\
\hline 1. & Accommodation for the students (male/female) is ample & 2.94 & 1.03 \\
2. & Prayer and common room facilities in the dormitories are pleasing & 2.56 & 1.03 \\
3. & Dining facilities in the students' dormitories are reasonable & 2.53 & 1.03 \\
4. & Cultural and recreational facilities in the dormitories are mentionable good & 2.41 & 1.03 \\
5. & Residential facilities for Faculty members and staff are plenty & 1.88 & 1.03 \\
6. & Residential facilities for guests are sufficient in BSMRAU & 1.41 & 1.03 \\
\hline
\end{tabular}

The reasons behind the findings might be that there is enough accommodation for the students as two new dormitories established but since 1996 no new establishments have been created for the teachers and staff as well. By this time the numbers of teachers and staff have been thrice. Most of the newly appointed bachelor teachers have been living in the outreach dormitory temporarily which is creating problems for outreach programs of the University. Other teachers and staff are residing outside the campus creating pressure on the transport system.

\subsection{Recreation facilities}

Recreation is an essential element for the mental freshness of an individual. Each University has a section involved with different recreational activities like music, drama, comedy shows, etc. BSMRAU as a University has some arrangements for recreational activities. Results shown in Table 12 indicate that the recreational facilities of BSMRAU were recognized as dissatisfactory. Cultural facilities (1.24) and other extracurricular activities (1.12) were found dissatisfactory due to the absence of cultural club and debating club on the campus though there is a provision of socio-cultural facilities. Students also cannot make time to be involved with the different recreational activities due to their intensive involvement in the course credit system academics. Moreover, there was no TSC (teacher-student center) in the campus.

Table 12. Opinion of the respondents on recreational facilities

\begin{tabular}{llcc}
\hline Sl & \multicolumn{1}{c}{ Statements } & $\begin{array}{c}\text { Average } \\
\text { score }\end{array}$ & SD \\
\hline 1. & Cultural facility at the cultural center is sufficient & 1.24 & 0.56 \\
2. & Teacher-Student Center (TSC) is well facilitated and developed & 1.14 & 0.37 \\
3. & There is a satisfactory extracurricular facility for the students & 1.12 & 0.36 \\
\hline
\end{tabular}

\subsection{Security measures}

Security is a vital fundamental need for any individual. In each organization, there is an inbuilt security system. In BSMRAU, there is a contingent of 60 armed security sentries along with 39 civil guards. They have been working under two security officers of the University. The law and order situation is controlled by the Proctor.

Information presented in Table 13 indicates that all the respondents were moderately satisfied with security services (2.42) and the competency of the security staff (2.16). This might be due to the reason that the civil security guards are employed directly without any previous security knowledge and there is no provision of training for them about the importance of security.

Table 13. Opinion of the respondents on security measures

\begin{tabular}{llccc}
\hline Sl & \multicolumn{1}{c}{ Statements } & Average score & SD \\
\hline 1. & $\begin{array}{l}\text { There are enough security measures to teachers, students, and staffs in } \\
\text { the campus }\end{array}$ & 2.42 & 0.91 \\
2. & $\begin{array}{l}\text { Security staffs are competent enough with necessary arms and } \\
\text { equipment }\end{array}$ & 2.16 & 0.95 \\
\hline
\end{tabular}

\subsection{Recruitment, promotion, development, and support}

Recruitment and promotion are continuous events for any organization. Recruitment is required to fill up the vacancy in a new post or vacated post. Promotion is given to an incumbent based on some criteria 
showing satisfaction. Satisfactory feedback was found for cooperation from faculties in laboratory or field (3.43) and cooperation from higher authority (3.14). Moderate satisfaction was found for the quality of recruited faculties (2.81), recruitment system (2.33), and promotion system (2.32). On the contrary, skill development facilities (1.71) and induction training facilities (1.24) were highly demanded by most of the respondents (Table 14). Some reasons might exhibit things like that. The University has been trying to recruit competent persons and provide a promotion to the eligible incumbent. A higher authority is always sensitive to academic quality and intimately provides all-out efforts when any academic problem arises. Training makes an individual effective to render his/her job efficiently. For areas of dissatisfaction, there is hardly any provision of imparting training to the newly recruited faculties and staffs to make them fit for the job assigned to.

Table 14. Opinion of the respondents on recruitment, promotion, development, and support

\begin{tabular}{rlcc}
\hline SI & \multicolumn{1}{c}{ Statement } & $\begin{array}{c}\text { Average } \\
\text { score }\end{array}$ & SD \\
\hline 1. Faculties are helpful while working in a laboratory or field & 3.43 & 0.76 \\
2. $\begin{array}{l}\text { Cooperation is available from higher athority (VC/Dean/Directors) } \\
\text { colleagues }\end{array}$ & 3.14 & 0.93 \\
3. Consult with colleagues and receiving their suggestion on teaching-learning is & 2.97 & 1.04 \\
a regular system & 2.86 & 1.04 \\
4. The department has a procedure to observe teaching & 2.81 & 1.02 \\
5. Entry qualification of teachers is up to the required standard & 2.67 & 1.01 \\
6. Students strictly follow the laboratory rules and regulations & 2.50 & 1.35 \\
7. Teachers workload in teaching - research is manageable & 2.38 & 0.95 \\
8. Performance appraisal is always maintained at BSMRAU & 2.36 & 0.94 \\
9. Teacher-course ratio in the respective department is justified & 2.33 & 0.84 \\
10. The recruitment system is satisfactory & 2.32 & 1.01 \\
11. Promotion system is satisfactory and fair & 2.14 & 1.03 \\
12. The compensation package of the University is satisfactory & 2.10 & 0.99 \\
13. The recruitment and appointment procedure is clearly stated & 1.94 & 0.85 \\
14. Peer observation is well accepted in the department & 1.86 & 0.99 \\
15. Peer observation technique is practiced to improve teaching quality & 1.71 & 0.86 \\
16. There are enough training facilities for improving the skills of the staffs & 1.24 & 0.57 \\
17. BSMRAU has an induction training program for all new staffs & & \\
\hline
\end{tabular}

\subsection{Student support and counseling}

Student support and counseling are very important for any student to overcome any simple as well as a complex problem. However, the following issues were considered to find out the status regarding the issue mentioned above. Information presented in Table 15 indicates that the statements for the admission procedure of BSMRAU was highly recognized as smooth and fair (3.57) while academic guidance and counseling from the departments (1.94) as well as from authority (1.94) and booklets for counseling materials (1.65) was not satisfactory. Moderate satisfaction was found in the online admission system (2.94) and maintaining an open-door policy for students by the teacher (2.82). All sectors related to admission procedure that is the scrutiny of the applicant, questioning, and evaluation of answer script and publication of results are maintained strictly without any biasness which might be the causes of highly favorable satisfaction in case of smooth and fair admission procedure. Respondents' opinion on student counseling was unsatisfactory because at present there is no existence of any kind of student counseling activity by the authority though there should have a provision of student counseling. 
Table 15. Respondents' opinion on support and counseling of student

\begin{tabular}{clcc}
\hline SI & \multicolumn{1}{c}{ Statement } & $\begin{array}{c}\text { Average } \\
\text { score }\end{array}$ & SD \\
\hline 1. & Admission procedure is smooth and fair & 3.57 & 0.70 \\
2. & Student can apply and get registration for admission through the online system & 2.94 & 0.87 \\
3. & Teachers maintain open-door policy for students & 2.82 & 1.15 \\
4. & University authority maintains communication with the employers & 2.58 & 0.75 \\
5. & University website for students' admission is informative & 2.55 & 0.91 \\
6. & Departments and dean/student affair and other student support service are well & 2.53 & 0.84 \\
& linked & 2.26 & 1.02 \\
7. & University helps students for employment and career development & 2.24 & 1.02 \\
8. & Students' progress occurred by academic guidance is satisfactory & 2.00 & 0.90 \\
9. & Extracurricular and co-curricular activities of the University are adequate & 1.94 & 0.88 \\
10. & Academic guidance and counseling system is satisfactory & 1.65 & 0.77 \\
11. & Booklets are available for students as a counseling material & & \\
\hline
\end{tabular}

\subsection{Knowledge and skill development}

Knowledge refers to facts, information, or familiarity of any object acquired through experience and education or knowledge is the theoretical and practical understanding of the facts. Skill is an observable competence to perform a learned psychomotor act. Knowledge and skills include education and training, as well as abilities gained through daily life. Knowledge and skills enhance people's ability to meet their basic needs, widen the range of options open to them in every sphere of life, and enable them to influence the direction their lives take. The skills people possess can also enhance their sense of self-worth, security, and belonging. Eight generic skills were considered for clarity of understanding.

Table 16. Respondents' opinion on skill development

\begin{tabular}{llccc}
\hline Sl & \multicolumn{1}{c}{ Generic skill } & Teacher & Student & t-test \\
\hline 1. & Cognitive skills & 3.53 & 3.14 & \\
2. & Practical and problem-solving skills & 3.73 & 2.77 & \\
3. & Numeracy and analytical skills & 2.29 & 1.96 & \\
4. & Entrepreneurship and innovation skills & 1.78 & 1.32 & $5.49 * *$ \\
5. & Communication and ICT skills & 1.88 & 1.07 & $(\mathrm{P}=0.001)$ \\
6. & Interpersonal teamwork and leadership skill & 1.88 & 1.35 & \\
7. & Self-management and personal management skill & 2.27 & 1.64 & \\
8. & Commitment to community and humanity & 2.08 & 1.70 \\
\hline
\end{tabular}

From the teachers' opinions, it is clear that the students possessed high-level of practical and problemsolving skill (3.73), cognitive skill (3.53) from the courses, whereas students indicate that they were highly benefited for cognitive (3.14) while moderately for practical and problem solving (2.77) skill development (Table 16). From the teachers' points of view, poor development occurs in case of communication and ICT skills (1.88), interpersonal teamwork and leadership skill (1.88) and entrepreneurship and innovation skills (1.78) whereas students opined that they are very poorly benefited for the development of interpersonal teamwork and leadership skill (1.35), entrepreneurship and innovation skills (1.32), and communication and ICT skills (1.07). Therefore, it is clear from Table 16 that the students are in a lower grade in terms of ICT and communication skills, entrepreneurship and innovation skills, and interpersonal teamwork and leadership skills which are very essential for getting any job and showing their time demanding performance. The t-test result indicates a significant difference between teachers' and students' perceptions of generic skills development.

\subsection{Overall quality of BS(Ag) program of BSMRAU}

Findings shown in Figure 2 reveal that among the different parameters, the overall mean score for the quality of teachers and staff, learning assessment strategies, teaching-learning, and classroom and office room facilities were $3.04,2.96,2.89$, and 2.74, respectively. However, the average score of recreational, sports, 
medical, and ICT facilities were found 1.17, 1.57, 1.71, and 1.81, respectively. Hence, considering the average score of different parameters and specific components under different parameters, special attention should be taken to uphold the recreational, sports, medical, and ICT facilities for the smooth functioning of the overall educational program and improve the quality of BS(Ag) program of BSMRAU.

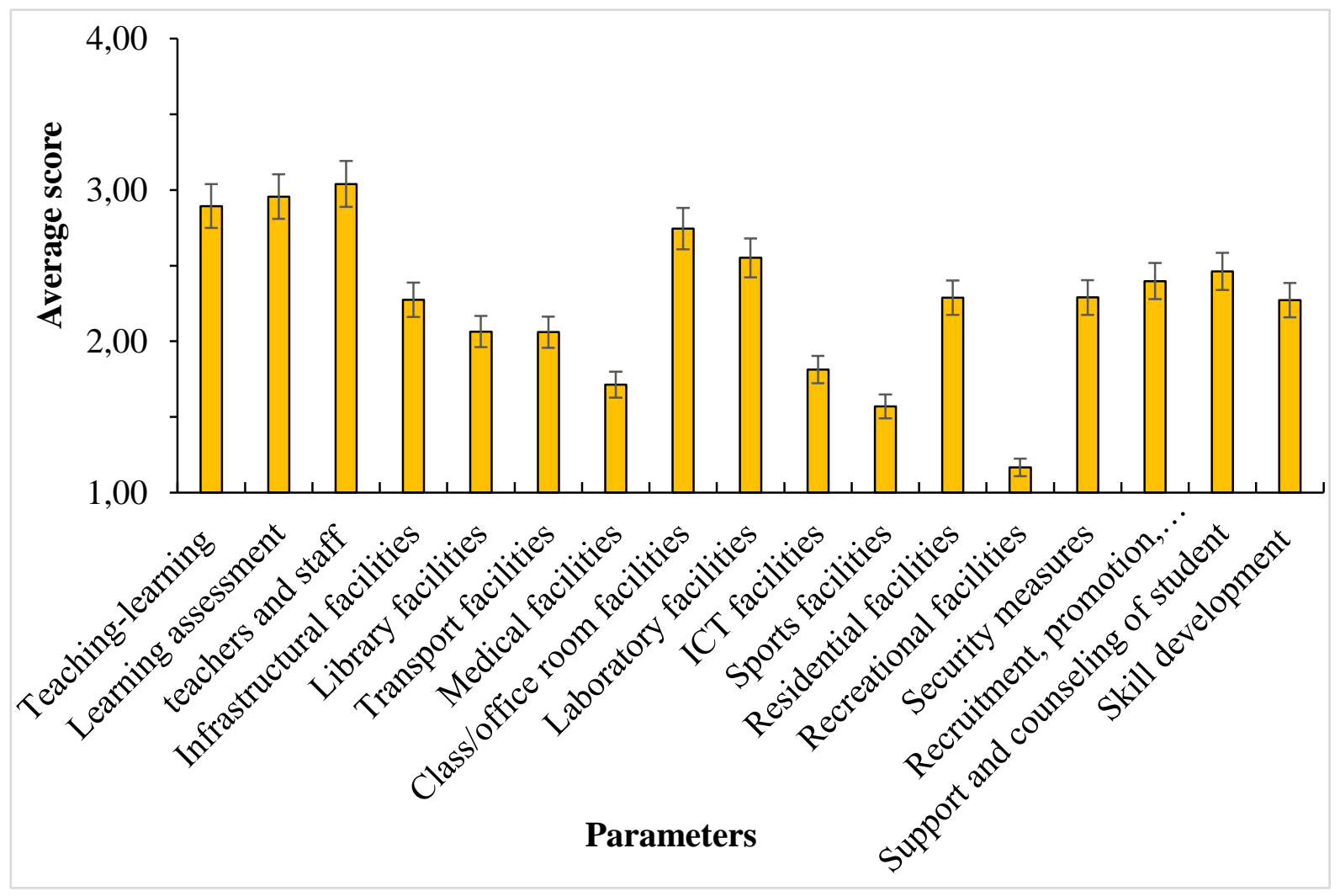

Figure 2. Overall score of different parameters of BS(Ag) program of BSMRAU

\section{Conclusion}

Feedback obtained from teachers and students and its implementation on the curriculum is not up to the mark. Teaching style has been found varied from instructor to instructor. Every student is not taken care of skillfully which leads to the failure of exploring individual potentiality. Early forecasting of assessment criteria with due execution and timely publication of results are highly appreciated. Teachers and laboratory technicians are well qualified. Foundation training for teachers on the teaching-learning method is reported very insufficient. Peer observation is rarely accepted and practiced in the department to improve teaching quality. Classrooms are well equipped with modern teaching aids but washrooms are not good enough. The laboratory environment is conducive to use sophisticated instruments but not appropriately arranged. Facilities for group study are inadequate in the central library. The number of computers in the laboratory and students' access to internet facilities is very limited. Residential facilities for the students are sufficiently enough but not for the faculty members, staff, and guests. Medical facilities are not satisfactory. Departmental stores, car parking spaces, and auditorium are substandard. Sports facilities are very poor at BSMRAU. Transport facilities for students, teachers, and staff are not good enough. Recreational facilities are below average while security measures are moderately sufficient (Afrad \& Barau, 2019).

Regular foundation training is essential to eliminate wide variation in teaching style. It is essential to be sensitive to every student matter (ESM) for exploring individual potentiality. Students' feedback on teaching-learning needs to be collected and communicated to the students regularly (Afrad \& Barau, 2019). There must be a usual provision for practicing peer observation in the departments to improve teaching quality. The number of computers with internet facilities in the laboratory needs to be increased for easy access for the students. Medical, sports, transport and recreational facilities need to be improved immediately considering the present demand and future as well. The departmental store should be established with modern facilities and car parking facilities should be arranged with adequate space. 
Students may be provided with printed materials on academic guidance during admission or orientation program. Students' counseling system needs reinforcement on an immediate basis. There should be such an arrangement in $\mathrm{BS}(\mathrm{Ag})$ program that each faculty can be a counselor of every five students likethat of the graduate program. Emphasis should be given to improve ICT and communication skills, entrepreneurship and innovation skills, and interpersonal teamwork and leadership skill of the graduates for their easy access to the job market at home and abroad (Afrad \& Barau, 2019). There should be strong and well defined Institutional Quality Assurance Cell (IQAC) and regular performance appraisal system of the staff in the Faculty of Agriculture.

Since program-level self-assessment in Bangladesh is in the initial stage, the challenge was to develop concepts that have to be used and specific criteria for describing the concept. Besides, along with the logistical constraints, it also creates a mixed feeling among those who participated in the assessment process (Busco et al., 2018). The constraints might also involve in the sampling process which could be overcome in future assessment by involving more stakeholders. The results of this study was based on the opinion of selected sampled respondents for a specific time and hence very difficult to generalize the quality of a university like BSMRAU. Furthermore, the result of this study is not static, rather it will change very first as different projects have initiated to improve the overall management of the BSMRAU, which signifies the periodic conduction of such self -assessment study to evaluate the impacts for developmental activities on changing the overall quality of BS(Ag) program of BSMRAU.

\section{Acknowledgments}

The SPM team gratefully recognized the financial support from World Bank funded HEQEP subproject of the University Grants Commission of Bangladesh (UGC) entitled "Self-Assessment of BS (Agriculture) Program of BSMRAU for Quality Assurance".

\section{REFERENCES}

Afrad, M. S. I., \& Barau, A. A. (2019). Employability of bachelor of science (Agriculture) graduates of Bangabandhu Sheikh Mujibur Rahman Agricultural University. Journal of Technical Education and Training, 11(2), 68-78. https://doi.org/10.30880/jtet.2019.11.02.007

Aminuzzaman, S. M. (2011). Quality issues of higher education in Bangladesh. Journal of General Education, $1(1), 1-15$.

Barnamala, M. T. (2015). Status, issues and prospects of quality higher education in Bangladesh: In the contest of global world. Bangladesh Research Publications Journal, 11(1), 79-86.

Busco, C., Dooner, C., \& D'Alencon, A. (2018). Universidad de Chile: Self-assessment and its effects on university's management. Higher Education, 75(3), 431-447. https://doi.org/10.1007/s10734-017-0148-7

Chaudhary, A. R., Gillani, S. Y. M., \& Iqbal, A. (2009). The Nexus between Higher Education and Economic Growth: An Empirical Investigation for Pakistan. Pakistan Journal of Commerce and Social Sciences, 3, 1-9.

Chowdhury, A. K. M. H. U., Haque, M. E., Hoque, M. Z., \& Rokonuzzam, M. (2012). Adoption of BRRI Dhan47 in the Coastal Saline areas of Bangladesh. Agricultural Journal, 7, 286-291. https://doi.org/10.3923/aj.2012.286.291

Geoffroy Pitta, E. (2014). Origen y características del sistema de aseguramiento de la calidad de la educación superior chileno. Revista Electrónica Interuniversitaria de Formación Del Profesorado, 3(17), 49-64. https://doi.org/10.6018/reifop.17.3.204051

Hoque, M. Z., Cui, S., Islam, I., Xu, L., \& Tang, J. (2020). Future impact of land use/land cover changes on ecosystem services in the lower meghna river estuary, Bangladesh. Sustainability (Switzerland), 12(5), 118. https://doi.org/10.3390/su12052112

Hoque, M. Z., Cui, S., Xu, L., \& Islam, I. (2019). Assessing Agricultural Livelihood Vulnerability to Climate Change in Coastal Bangladesh. International Journal of Environmental Research and Public Health, 16(22). https://doi.org/https://doi.org/10.3390/ijerph16224552

Monem, M., \& Baniamin, H. M. (2010). Higher Education in Bangladesh: Status, Issues and Prospects. Pakistan Journal of Social Sciences, 30(2), 293-305.

Nasim, F. A., Hoque, M. Z., Haque, M. E., Islam, M. S., Parveen, N., Chakma, S., \& Afrad, M. S. I. (2019). How Does Adoption of Crop Variety Reduce the Impact of Drought in Agriculture and Mitigate Food Insecurity of Smallholder Farmers? A Case Study on BUdhan1 Rice Variety in Bangladesh. Asian Journal of Agricultural Extension, Economics \& Sociology, 30, 1-12. 
https://doi.org/10.9734/ajaees/2019/v30i330114

OECD. (2019). Education at a Glance 2019. In Education at a Glance: OECD Indicators. https://doi.org/10.1787/f8d7880d-en

Rahman, M. A. (2010). Commercialisation of education in Bangladesh: Problems and solutions. NAEM Journal, 5(10), 1-11.

Rodr'iguez, D. (2005). Diagnóstico del clima organizacional. Diagnóstico Organizacional, 159-178.

Sarkar, S. H., Rana, S., \& Zitu, R. A. (2013). Challenges of Quality Higher Education in Bangladesh: A Study on Public Universities. Jounal of Education and Practice, 4(8), 151-160.

Schein, E. H. (2005). Organization development: A wedding of anthropology and organizational therapy. Reinventing Organization Development: New Approaches to Change in Organizations, 131-143.

Torre, D., \& Zapata, G. (2012). Impacto de procesos de aseguramiento de la calidad sobre las instituciones de educación superior: un estudio en siete países. In Aseguramiento de la Calidad en Iberoamérica. Educación Superior Informe 2012. https://doi.org/10.1007/978-90-481-3754-1

Villalta, O. M. V. (1998). Autoevaluación, autorregulación y acreditación: retos de la educación superior. Revista Educación, 22(2), 101-113. 